\title{
Development of a mechanism for assessing the economic sustainability of small enterprises
}

\author{
Roman Golov ${ }^{1}$, Igor Alkhimovich ${ }^{2, *}$, Valerij Kazarnovskij ${ }^{3}$ and Elena Ermolaeva ${ }^{1}$ \\ ${ }^{1}$ Moscow Aviation Institute, Volokolamskoe highway, 4, Moscow, 125993, Russia \\ ${ }^{2}$ Northern (Arctic) Federal University named after M.V. Lomonosov (Koryazhma branch), Lenina 9, \\ Koryazhma, 165651, Russia \\ ${ }^{3}$ Moscow State University of Civil Engineering, Yaroslavskoye shosse 26, Moscow, 129337, Russia
}

\begin{abstract}
The relevance of this study is due to the lack of a scientifically developed concept of the formation of sustainability indicators for small enterprises operating in the environmental field. The purpose of the study is to develop a mechanism for the economic sustainability of environmental organizations, which is based on competition, centralization of management, and business activities. In addition, the paper analyzed the modern theory and practice of managing production structures, studied the main factors affecting the system of indicators of the organization's sustainability. A methodology that allows for diagnostics and assessment of the sustainability of an enterprise is proposed. The financial mechanisms that ensure the process of financing environmental activities are studied.
\end{abstract}

\section{Introduction}

In the scientific economic literature, considerable attention is paid to the definition of the essence of the economic sustainability of enterprises. There are various options for its interpretation. The current state of the theory of sustainability of enterprises is characterized by a multitude of scientific fields and conceptual approaches, as well as a lack of consensus on its economic essence and assessment criteria. Therefore, questions of the formation of the concept and types of economic sustainability, the classification of criteria and factors affecting it are relevant in scientific terms [1].

In market economy conditions, any organization should be considered as a complex, multifunctional, open production and socio-economic system operating in conditions of uncertainty and a changing external environment. Innovative methods of managing economic sustainability and its aspects are a special field of science, which is gradually evolving from highly applied research to the study of the most complex issues. This makes it possible to understand that many organizations still do not have an adequate behavior pattern that ensures their high stability in the market.

\footnotetext{
*Corresponding author: i.alkhimovich@narfu.ru
} 


\section{Materials and methods}

Sustainability is characterized as the ability of a system to withstand the process of destruction and maintain a selected mode of operation for a certain time. The assessment of the economic sustainability of organizations is based on a comparison of economic benefits and economic costs. Changes in market conditions, competition, as well as internal and external factors can lead to both positive and negative changes in the sustainability of the enterprise. Therefore, sustainability should be considered as a systematic, not an accidental phenomenon $[2,3]$.

Theoretically, the condition of enterprise sustainability can be expressed by the following inequality:

$$
D-C-(F+I)>0 \text {, }
$$

where D - the income from sales of products; C - the cost of production; F - fiscal payments; I - the amount of investment for development.

On this basis, most of the techniques come down to defining a number of criteria for economic sustainability (as a rule, by expertise), calculating the coefficients, and deriving an integral sustainability indicator using the formula:

$$
U=\sum_{i=1}^{n} K_{i} \cdot d_{i} ; \sum_{i=1}^{n} d_{i}=1(100 \%)
$$

where $\mathrm{U}$ - the integral indicator of economic sustainability, $\mathrm{Ki}$ - the calculated value of the i-th coefficient of economic sustainability; di - the share of the influence of the i-th coefficient on the integral indicator of economic sustainability.

Sustainability management will be based on the results of the previous assessment, measures to improve economic sustainability that are based on the results of the assessment, on the feedback system and ongoing monitoring of economic sustainability. The model of the mechanism of economic sustainability is presented in Figure 1.

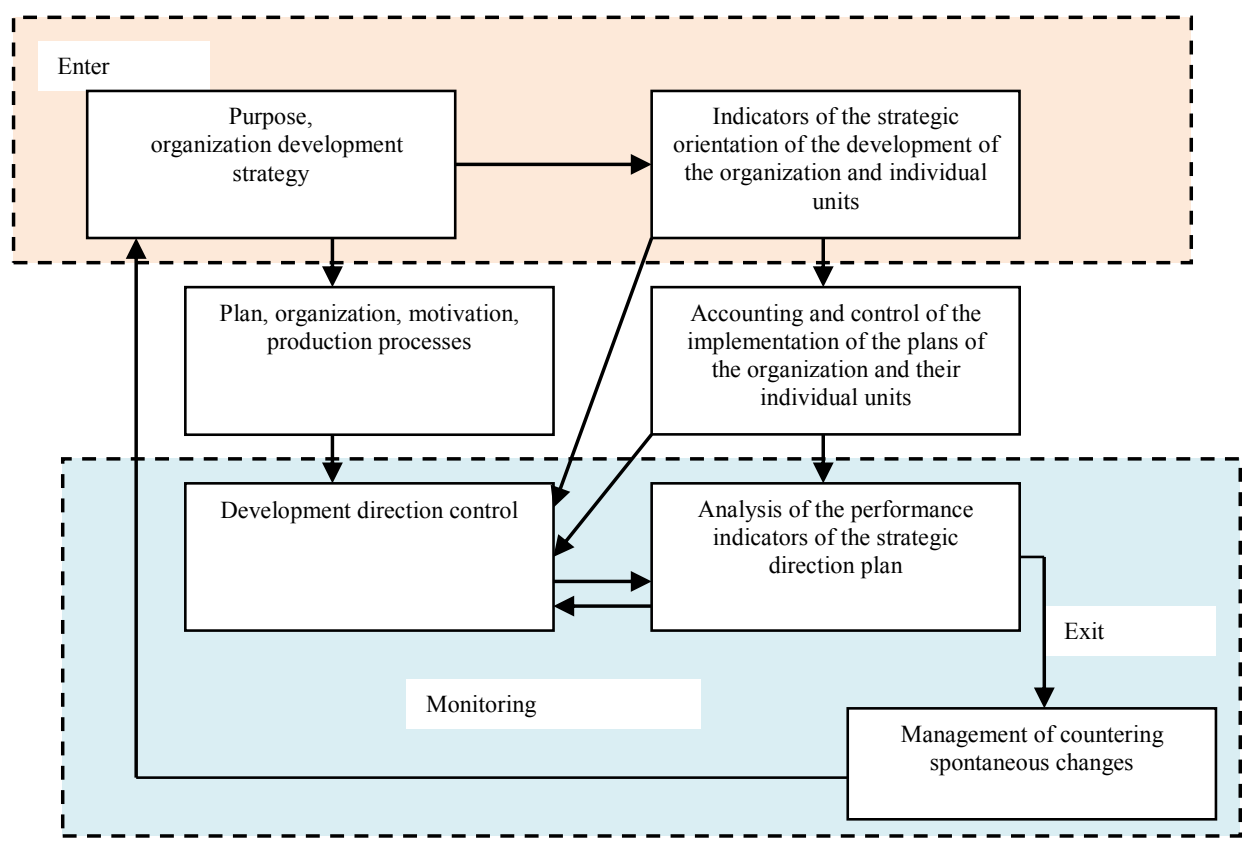

Fig. 1. The model of the economic sustainability of the enterprise. 
The model is based on the organic unity of all three types of activity, which provides necessary and sufficient conditions for economic sustainability. Before making a management decision regarding the management of the economic sustainability of an enterprise, it is necessary to assess the level of economic sustainability at the current moment, to determine the factors influencing it and the reasons that need to be eliminated or reduced [4].

The most important areas for improving the sustainability of an organization are: the formation of an adequate production program, the organization of the supply of materials and products, the operational management of production, the organization of product sales, the development of competitive products, the management of production restructuring projects, and the management of investment.

\section{Results}

Let us consider the main factors that may affect the sustainability of an enterprise, i.e. specific events and trends grouped by area of necessary information, i.e. by the main sections of market research.

Sustainability factors - causes that may cause a violation (increase or decrease) of sustainability are classified depending on the environment of occurrence, the nature and direction of the impact, the object of impact, etc.

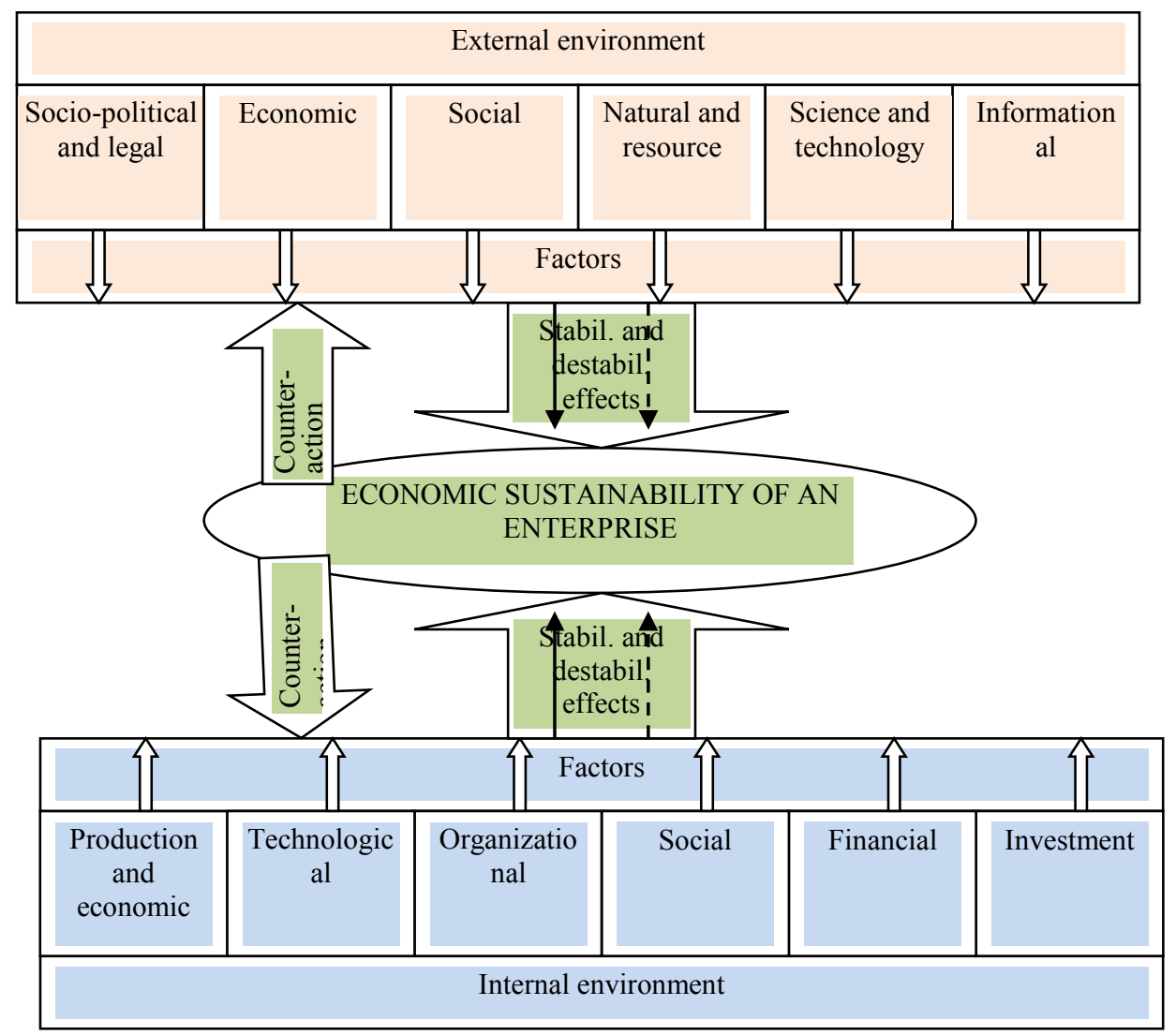

Fig. 2. The influence of external and internal environment on the economic sustainability of an enterprise. 
In this paper, we divide all factors into three levels: macro, meso, and mini-economic.

Macro-level factors reflect the general state of the economic system, the balance of monetary, credit, tax, tariff, customs, industrial, social policies, as well as the investment climate.

Meso-level factors are aimed at ensuring sustainable improvement of efficiency indicators of the use of research and production resources of industries.

The factors of a mini-economic level reflect the peculiarities of the organization of the main and auxiliary business processes at the enterprise level.

At the same time, in the traditional classification of factors into external and internal, macro-level and meso-level factors can be attributed to factors of the external environment, and mini-economic level factors to internal factors.

Macro and meso-level factors are considered as factors beyond the control of the enterprise's impact: an enterprise must be able to predict, adjust and adapt to them.

It is only possible to manage the mini-economic level factors at the enterprise level. In this regard, the main task of an enterprise in managing economic sustainability is the ability to identify the key causes of sustainability and competently influence them [5]

Based on the analysis of a significant amount of work, the main reasons affecting the economic sustainability of an enterprise were identified, and a classification of the key factors of the mini-economic level influencing the economic sustainability of an enterprise was developed (Table 1).

Table 1. Key factors of a mini-economic level that influence the economic sustainability of an enterprise.

\begin{tabular}{|c|c|c|c|}
\hline $\begin{array}{l}\text { Marketing } \\
\text { business } \\
\text { processes }\end{array}$ & $\begin{array}{c}\text { Production and } \\
\text { technological business } \\
\text { processes }\end{array}$ & $\begin{array}{c}\text { Financial and } \\
\text { economic business } \\
\text { processes }\end{array}$ & $\begin{array}{c}\text { Organizational business } \\
\text { processes }\end{array}$ \\
\hline 1 & 2 & 3 & 4 \\
\hline $\begin{array}{l}\text { 1. Dependence } \\
\text { on the } \\
\text { consumer } \\
\text { (level of } \\
\text { monopsony) }\end{array}$ & $\begin{array}{l}\text { 1. Production } \\
\text { efficiency (use of } \\
\text { production resources) }\end{array}$ & $\begin{array}{l}\text { 1. Efficiency of } \\
\text { production and } \\
\text { economic activity }\end{array}$ & $\begin{array}{l}\text { 1. Management organization } \\
\text { level }\end{array}$ \\
\hline $\begin{array}{l}\text { 2. Consumer } \\
\text { reliability }\end{array}$ & 2. Quality system & 2. Financial stability & $\begin{array}{l}\text { 2. Management } \\
\text { automation level }\end{array}$ \\
\hline 3. Market share & $\begin{array}{l}\text { 3. Level of } \\
\text { diversification }\end{array}$ & 3. Enterprise solvency & $\begin{array}{l}\text { 3. Level of organization of } \\
\text { personnel management }\end{array}$ \\
\hline \multirow[t]{5}{*}{$\begin{array}{l}\text { 4. Marketing } \\
\text { policy } \\
\text { effectiveness }\end{array}$} & $\begin{array}{l}\text { 4. Level of production } \\
\text { organization }\end{array}$ & $\begin{array}{l}\text { 4. Working capital } \\
\text { management } \\
\text { efficiency }\end{array}$ & $\begin{array}{l}\text { 4. Qualification of } \\
\text { management and staff }\end{array}$ \\
\hline & $\begin{array}{l}\text { 5. Duration of the } \\
\text { production cycle }\end{array}$ & $\begin{array}{l}\text { 5. Financial } \\
\text { independence }\end{array}$ & $\begin{array}{l}\text { 5. Leakage of qualified } \\
\text { personnel (employees' } \\
\text { dissatisfaction) }\end{array}$ \\
\hline & $\begin{array}{l}\text { 6. The age composition } \\
\text { of equipment, wearing } \\
\text { of equipment }\end{array}$ & 6. Tax planning & 6. Wage rate \\
\hline & $\begin{array}{l}\text { 7. Innovative activity } \\
(\mathrm{R} \& \mathrm{D})\end{array}$ & & 7. Management efficiency \\
\hline & $\begin{array}{l}\text { 8. Production potential } \\
\text { of an enterprise }\end{array}$ & & \\
\hline
\end{tabular}

A feature of the proposed classification is that the mini-economic factors are represented by four interdependent blocks of factors, which, on the one hand, characterize the area of possible occurrence of a problem, and on the other, the internal object of its direct impact (production, product, management, personnel). 
The developed classification of the key factors of the mini-economic level will make it possible to determine the most important areas of analysis of the enterprise's work in order to assess its sustainability and prospects for its improvement. There are two options for analyzing and making management decisions on its basis:

1) when the top management of an enterprise, for example, in the course of substantiating a development strategy, determines the most important management objects from the inside, and, accordingly, focuses its attention on factors affecting the selected objects (product development, personnel development, etc.). Therefore, in this case, preference will be given to monitoring changes in these factors;

2) when the top management of an enterprise learns about a change in a factor from the outside, it analyzes what threats may be associated with these changes (impact on other factors) and which object within the enterprise they will most affect. For example, new marketing techniques of competitors (which is difficult to predict) not only require changes in the marketing policy of the enterprise but also intensify the analysis of consumer behavior, product mix and price policy, quality and competitiveness of the product of both the assessed enterprise and the competitor.

Thus, the use of the classification of factors of economic sustainability allows assessing the state of an enterprise and make management decisions. The selected factors will indicate the direction of the enterprise's development and the possibilities of increasing its sustainability [6].

In accordance with the proposed classification of key mini-economic factors of economic sustainability of an enterprise, quantitative indicators that best assess the impact of a factor are determined to assess the impact of each of them. Further implementation of the procedure for assessing the level of economic sustainability of an enterprise consists of the following steps:

1) assessment of the level of influence of each factor on the economic sustainability of an enterprise by an expert method, the calculation of its weight;

2) checking the consistency of expert opinions;

3) calculation of a system of indicators that assess the influence of mini-economic factors on the economic sustainability of an enterprise;

4) bringing the calculated indicators to a single measurement system;

5) search for the average value of the factors assessed by several indicators;

6) calculation of the final value of the indicator of economic sustainability of an enterprise - the index of economic sustainability (Ies);

7) final assessment of the state of an enterprise in accordance with the selected rating scale.

The presented procedure for assessing the level of economic sustainability of an enterprise is a key element of the sustainability management system and at the same time, some stage of the enterprise sustainability management process. Combining these elements, we present the main stages of the process of managing the economic sustainability of an enterprise on the diagram (Fig. 3). 


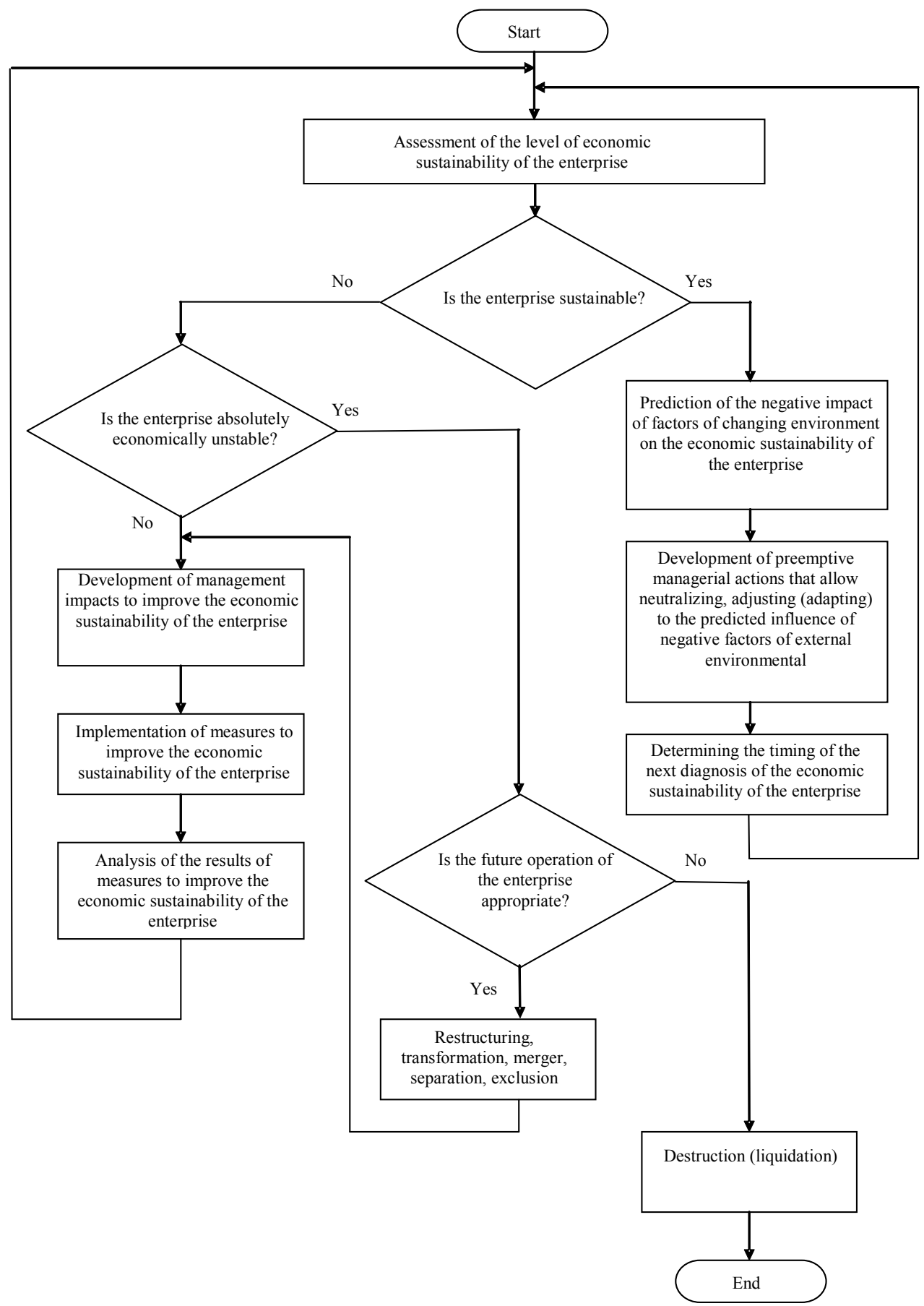

Fig. 3. The scheme of the management process of economic sustainability of an enterprise.

Sustainability management will be based on the results of the previous assessment, measures to improve economic sustainability that are based on the results of the assessment, on the feedback system and ongoing monitoring of economic sustainability. 
The initial prerequisite for choosing the criteria for assessing the sustainability of an organization is to establish key aspects of its activity $[7,8]$.

\section{Discussion}

The possibility of sustainable development of an enterprise is determined by the extent to which it succeeds in meeting the requirements for financial, industrial, natural, and social environments. The success of the organization operation in a financial environment is determined by its financial stability.

The impact on the organization of the production environment is manifested in two aspects: the creation of environmentally friendly products that are in demand among consumers, and the creation of conditions for effective and safe labor for the staff. And finally, the social environment imposes its requirements on the organization from the standpoint of compliance with labor laws, the implementation of social guarantees, public activity, and business ethics.

\section{Conclusion}

The implementation of the proposed algorithm will allow an objective assessment of the degree of economic sustainability of an enterprise. It will also allow identifying and tracking the dynamics of key sustainability factors, making variant forecasts of the enterprise's development, and taking priority measures to ensure sustainability depending on changes in key factors.

\section{References}

1. V. Mokeev, E. Bunova, A. Perevedentceva, Procedia Engineering 129, $681-689$ (2015)

2. P.K. Ozili, Borsa Istanbul Review 18(4), 329-340 https://doi.org/10.1016/j.bir.2017.12.003

3. J. Kádárová, R. Bajus, R. Rajnoha, Procedia Economics and Finance 23, 953 - 958 (2015)

4. B. Marchi, M. Pasetti, S. Zanoni, Enrgy Proced 113, 127-134 (2017) DOI: 10.1016/j.egypro.2017.04.034

5. B. Hirtle, A. Kovner, J. Vickery, M. Bhanot, Journal of Banking \& Finance 69(1), 35 55 (2016)

6. J. Creel, P. Hubert, F. Labondance, Economic Modelling 48, 25-40 (2015)

7. P-R. Agénor, L. Pereira da Silva, Journal of Financial Stability 28, 143-162 (2017) 